\title{
Online Political Participation: A Study of Youth Usage of New Media
}

\author{
Ali Salman ${ }^{1}$ \\ Suhana Saad ${ }^{2}$ \\ ${ }^{1}$ Associate Professor, Faculty of Social Sciences and Humanities, the National University of Malaysia \\ asalmanphd@gmail.com \\ ${ }^{2}$ Associate Professor, Faculty of Social Sciences and Humanities, the National University of Malaysia \\ suhanasaad@ukm.edu.my
}

\section{Doi:10.5901/mjss.2015.v6n4s3p88}

\begin{abstract}
The Internet is considered a huge development in human civilization. It is literally considered as a practical key or essential to human development and social advancement causing massive innovation in the world. Over the years, the advent of new media has permeated most aspects of our lives, especially that of the young generation. It is against this background that this paper aims to analyse the present use of the new media by youth to gauge their usage in relation to political participation. This study is a country wide survey covering Peninsula and East Malaysia. For sampling purposes the country is divided into six zones. A survey research using questionnaire as instrument was used to obtain data. Prior to the actual survey, a pilot study was first conducted. Some 1182 respondents age between 18 and 25 were randomly sampled from the six zones and selection of samples was based on ethnic ratio. The data was analysed descriptively and inferentially using SPSS 20.0 From the results, majority of the respondents, $89 \%$ are social media users having a social media account. A discouraging trend with regard to participation is the very low level of giving comments on general societal issues ranging from social issues, the environment to politics. The youth are more inclined to using the new media for entertainment and social networking. It is time to use the new media to engage with community leaders and politicians and comment on issues related to political issues.
\end{abstract}

Keywords: New media; youth; political participation; internet; social media

\section{Introduction}

The Internet is considered a huge development in human civilization. It has become the main sharing tool around the world and enables people to create massive developments for many countries that are interconnected. Furthermore it creates very large, heavy and solid interconnectivity. It is literally considered as a practical key or essential to human development and social advancement causing massive innovation in the world (Firas H. Al-Hammadan and Almas Heshmati 2011). Internet is viewed as an environmental element with potential for developmental impact (Johnson 2010).

Over the years, the advent of new media has permeated most aspects of our lives, especially that of the young generation. New media, especially the Internet has gained popularity among young people wherever they might be and in spite of significant differences among the developed and developing world, the use of computers and the Internet is rising steadily, fastest among young men (Gigli 2004). It is a household name coupled with its ubiquitous nature. The youth which includes the generation $Y$ or the millenials are associated with the new media (Palfrey and Gasser, 2008). As leaders of tomorrow they are supposed to use the new media to get involved in political participation.

Youth are said to be 46 percent of the total global population and can be defined as a person who is still in their formative years, undergoing character modelling, personality development and sometimes receiving training that has to do with human capital development. Youth is an important human capital development in the process of national building due to the great potential they have (Kayode 2011).

New media play an important role of transformative social change. It has an overall impact on youth physically, socially, and intellectually (Weigel et al. 2009). The rise of new media has already brought several main changes in life. They are digitalization and convergence of all features of media, increasing interactivity and network connectivity, mobility and delocation of sending and receiving, adaptation of publication and audience roles, appearance of diverse new forms of media 'gateway' and fragmentation and blurring of the media instution (McQuail 2010).

Like the conventional media, the power and facilities of the new media can also be harnessed for online political participation. Waller (2013) found that youth participation is now turning into online political debate in the United States, 
Europe and the Middle East. Social media play an important role in shaping the political debate with increasing discussions about democracy and civil rights on Twitter, Facebook, YouTube or democracy street ( Wojcieszak 2013). In West Asia, the people share their anger through new technology due to the inability of Arab leaders to meet their basic expectations. Public outrage prompted millions of Arab youth to unite to demand change in leadership and the government, whether in the form of online or offline (Foley 2013) .

Based on quantitative data, this paper aims to analyse the present use of the new media by youth to gauge their usage in relation to online socio-political participation. Hence, their online and offline participation will be analysed.

\section{Literature Review}

Political participation is an activity carried out in order to influence decisions made by the government. This participation can be done through formal or informal association, individually, group, legally or illegally (Huntington and Nelson 1963). Milbrath and Goel (1977) argue that many forms of political participation only focus on voting behavior. Actually, many activities can be considered as political participation. These include campaign, contacting public officials, reading and distributing political pamphlets, joining political organizations, donating money, working with local government, and engaging in community activities. In addition, demonstrations, protest, riots are also other types of political participation. Expanding the concept further, one can include online participation and the difference being a matter of platform in the sense that online involves a virtual space, whereas offline has to do with physical space.

Three fundamental technical changes in ICTs are responsible for the explosion in their use to promote economic development. They are plummeting cost that allowed many people and applications that could not afford to communicate in the past to link, expanding access to the network, and more powerful human to machine interfaces which allow new users to understand how to use the services without manuals, instruction, or translation (Kirkman et al. 2002).

Although the Internet has consistent positive impacts on modern society, a recent study by Firas H. Al-Hammadan and Almas Heshmati (2011) on determinants of Internet use in Iraq indicates that while Iraqis are eager or full of excitement to adopt this technology in order to reach out to the world, a number of factors are not allowing it to become a public domain. Factors include lack of adequate resources, insufficient incentives and encouragement from the government, and social inhibitions. Hence, for the Internet to be adopted fully for development and nation building purposes, encouragement and support must come from the government.

Several studies in regard to relathionship between new media practices by youth and nation building has been done. Wallis (2011) studies on new media practices in China through four broad themes: networked community and identity, gaming, networked public sphere and civic engagement, and new media consumption. The findings show that diverse new media practices emerge in China within the tensions and contradictions of the government's desire to simultaneously expand new media technologies and control what are perceived as "harmful" influences. Within a highly commercialized and more liberalized sociocultural environment, new media technologies have opened up new spaces for multiple modes of expression, and as such, they are constitutive of complex processes of social change.

New media like Facebook, Twitter, Google+, YouTube, live blogs, podcasts, webcams, smartphones, or tablets play in the post-modern, on-demand, interactive, and open societies of today. Changes in access to technology have facilitated new conditions for young people to shoot, cut, and mix multimodal texts, and the emergence of the Internet as a convergent multimedia vehicle and a hang out for a global audience has enabled youth to communicate across borders and across the street (Hoechsmann 2008).

New media has power. For example using social media to mobilise political participation initially gained prominence during the 2008 US presidential election, when then-Senator Barak Obama successfully employed a social media platform that incorporated Web 2.0 applications such as Facebook, Twitter and YouTube to make a range of self organising tools available to young users. The recent events in Tunisia, Egypt, the UK and the USA leave little doubt that the role of new technology in youth political mobilisation extends beyond the Obama paradigm (Theocharis 2011).

In Malaysia, the 2008 General Elections showed the keyboard warriors play an important role during the election campaign. According to Deputy Prime Minister Dato ' Seri Najib Razak, the ruling party failure to understand the impact and influence of new media caused several states to fall to the opposition. During the 2008 general elections, blog had become a major source for information in political developments. Nowadays, Facebook, twitter and instant messaging apps such as WhatsApp are also playing important role for political participation.

Social interaction occurring through social networks has provided opportunities for individuals to be exposed to different sources of information (McClurg 2003). Political participation has greatly been influenced by social interactions. Marco and Grace (2011) have identified whether social sites like Facebook and video games are related to political participation. They found that Facebook and video game have relevance to political participation, either online or in 
traditional form. Therefore, Porta and Mosca (2005) argue that the involvement of young people in politics is no longer as before. They are now engaged in political debate and show interest in politics through different ways, namely through social media. The same opinion was obtained from survey by Vromen (2007) in Australia. He found that a digital usage divide exists between those aged 18 to 34 years and those who are 35 and above. Young candidates who contest elections tend to use the internet as a medium for campaigning.

\section{Research Design}

This study is a country wide survey covering Peninsula and East Malaysia. For sampling purposes the country is divided into six zones consisting of four zones in Peninsula Malaysia and two in Sabah and Sarawak.

A survey research using questionnaire as instrument was used to obtain data. Prior to the actual survey, a pilot study was first conducted to test the respondents' understanding of the questionnaire. Respondents for this study were randomly sampled from the six zones and selection was based on ethnic ratio, age and gender using an already prepared sampling frame table. The age of respondents range from 18 to 25 and there was fairly equal number of males and females. Some 1182 respondents were sampled from the six zones. Base on the ethnic ratio of the country, most of the respondents are Malays. The data was analysed using SPSS 20.2 and and analysed descriptively.

\section{Findings}

Of the total number of respondents who were surveyed, $59.8 \%$ have Internet subscription. Moreover there is a significant difference between the total number of respondents who have social media account. The majority of respondents were social media users (89\%) and only $11 \%$ did not sign up for an online social media account.

Table 1. Internet subscription / Social Media Account

\begin{tabular}{lcc}
\hline & Frequency & Percent \\
\hline Internet Subscription & 705 & \\
Yes & 473 & 59.8 \\
No & & 40.2 \\
Social Media Account & 1048 & 89 \\
Yes & 130 & 11 \\
No & & \\
\hline
\end{tabular}

Table 2 indicates the means for the Internet and social media activities of the respondents. The results show that information search is the most common activities among the respondents $(M=2.92)$, followed by chatting with friends $(M=2.85)$, surfing the web $(M=2.81)$, interacting and communicating with new and old friends $(M=2.76)$, downloading activities such as music, pictures and videos $(M=2.60)$ and sending and receiving email $(M=2.54)$. This shows that e-mail which was the main usage of the Internet, has now been overshadowed by other usage.

Table 2. Internet / Social Media Activities

\begin{tabular}{lll}
\hline & Mean* & Standard Deriation \\
\hline Chatting with Friends & \\
Surfing the web & 2.85 & .96 \\
Sending and receiving email & 2.81 & .88 \\
Information Search & 2.54 & .97 \\
Download music/picture/video & 2.92 & .92 \\
Interaction with new and old & 2.60 & 1.01 \\
friends & 2.76 & .92 \\
& & \\
\hline *Mean = 0 (never) to 4 (very frequent) & &
\end{tabular}

Table 3 presents the offline participation by the respondents. Among the offline activities, the most common activities is discussing current issues featured in the media $(M=2.25)$. This is followed by involvement in welfare work ( $M=1.94)$, 
helping the poor and the needy (M=1.83), volunteering in teaching the less fortunate teens $(M=1.63)$ and giving opinion for policy formulation (M=1.61). Thus, except for discussing current issues featured in the media, the respondents' offline participation is below average.

Table 3. Offline Participation

\begin{tabular}{lcc}
\hline & Means* & Standard Deriation \\
\hline Involve in Welfare work & 1.94 & .81 \\
Helping the poor and the needy & 1.83 & .84 \\
Giving opinion for policy formulation & 1.61 & .76 \\
at workplace or area of resident & & \\
Volunteer in teaching less fortunate teens & 1.63 & .81 \\
Discussing current issues in the media & 2.25 & .88 \\
& & \\
\hline *Mean = 0 (never) to 4 (very frequent) & &
\end{tabular}

Data in Table 4 indicate that the majority of the respondents are interested in online disscussion group $(M=1.49)$. This is followed by commenting on blog post or articles $(M=1.43)$, uploading and downloading video as a protest $(M=1.38)$, commenting on online newpapers ( $M=1.31)$ and sending comments to the editor trough e-mail $(M=1.28)$. Similar to offline participation, the means for online participation are also below average.

Table 4. Online Participation

\begin{tabular}{lll}
\hline & Means* & Standard Deviation \\
\hline Commenting to the editor & 1.28 & .60 \\
through email & & \\
Commenting on online newspaper & 1.31 & .65 \\
Commenting on blog post / articles & 1.43 & .74 \\
Involve in online discussion group & 1.49 & .78 \\
Uploading and Downloading video & 1.38 & .75 \\
as a protest & & \\
*Mean = (never) to 4 (very frequent) &
\end{tabular}

\section{Discussions}

The Internet, especially Social Media (SM), is often associated with the youth who are seen to be more attached to the SM. Youth who belong to the generation $Y$ are said to be natives of the new media. For them the new media is part and parcel of their lives. As this study shows 89 percent of the youth interviewed have SM account. However, only about twothirds (59.8 percent) of the youth interviewed have internet subscription. This might be due to the fact that some of the youth interviewed were still studying coupled with the fact that for some of these youth Internet subscription is still expensive. Also internet is now available free at universities, working place, restaurants and cafes. The young generation is familiar with surfing, reading, reacting and creating political messages on the Internet Moeller (2014).

With most of the youth having SM account, SM has the potential to serve as a platform to galvanise the youth for a meaningful political participation. Thus the public sector can take advantage of this development to engage the youth in a meaningful participation which may translate to political participation. WhatsApp is a new media app that is frequently used by youth and this is different from the findings by Carolyn Lim et al. (2013) who found that youth are surfing more Facebook, Twitter and multimedia sites such as YouTube. The youth are more active in new media for social interactions. They prefer to use online media to express their opinion with group discussions that explore contemporary issues through social media such as Facebook, Twitter and blog (Azmah et. al 2013).

As distinct from the generation $\mathrm{X}$ who are the older generation, the youth who are considered generation $\mathrm{Y}$ tend to use the new media more for their activities. This study showed that the common activities in order of importance include information search, chatting with friends, and sending and receiving email. This shows that e-mail, which was the main usage of the Internet, has now been overshadowed by other functions. For the youth, especially those who were not working, email use was not a priority for using the Internet. Youth navigate the new media through two ways. First, join social networking sites such as Facebook, Twitter, and multimedia sites such as YouTube. Second, youth surf websites like wikis and blogs. Many influential friends influence them in the selection of their participation in new media, such as 
Facebook, Twitter, or Tumblr. Therefore, the new media can bring online relationship to an offline reality (Carolyn Lim et al 2013).

When it comes to online participation, the findings indicate that the youth more in online disscussion groups, which is very low, participation in other aspects is much lower. Likewise, in terms of offline participation, except for discussing current issues featured in the media, the youth's offline participation is below average. Hence, not encouraging and this could be due to the lack of interest in politics by Malaysian youth who are by and large comfortable with their lives and therefore not bothered with issues related to politics.

From the foregoing, one may ask where lies the empowerment? This is because literature shows the capability of the Internet in political participation, especially by youth; hence not using it as such is a waste of resource. Does it mean that our youth use the Internet for diversion and not for empowerment which may lead to political participation? These questions and others need answers from which lasting solutions can be derived to make the youth more involved in political participation by way of participating online through commenting on national and social issues. This is due to the fact that most of the offline activities are the continuation of online activities (Noris 2003; Kawasaki 2003; in Samsudin A.Rahim 2010).

As distinct from the youth in Malaysia, studies have shown that youth in other third world countries are actively using the internet for political participation and activism. The 2014 gathering TURUN (movement to express the anger of the people against price increases and cost of living) mostly involved youth. The emergence of youth in political movements and active participation in the democratic process occurred because these people have different political ideas. Loader (2007) described the youth as "Internet generation", and Livingstone et al. (2007) claimed that they have the right to have their voices heard and form online communities that allow for voicing their movements.

\section{Conclusion}

The objective of this paper is to analyse the present use of the new media by youth to gauge their usage in relation to political participation. The findings have shown that the youth in Malaysia are exposed to political participation online. Recently online political participation has mobilized opposition to the government's decision related to the implementation of GST (Goods and Services Tax), price increases, religious issue and etc. However, the youth are more inclined to using the new media, social media to be precise, for entertainment and social networking. It is time to shift to more empowered usage such as using the new media to engage with community leaders and politicians and comment on issues related to political development. Failing this, will be a waste of resource made available by the new media for citizen participation and decision making. Based on the finding, further studies can be conducted in the context of online political marketing among youth in Malaysia especially how youth can play their role in promoting a party's strategy in election.

\section{References}

Azmah Ab. Wahab \& Samsudin A. Rahim. (2013). Kredibiliti media dan penyertaan dalam persekitaran pendemokrasian maklumat di Malaysia. Jurnal Komunikasi Malaysian Journal of Communication, 29, 141-160.

Carolyn Lim, Victor Chen Der Thanq, Rose Liang. (2013). Singapore youth's new media participation: Consuming, being, learning and schooling. Procedia - Social and Behavioral Sciences, 93, 727-731.

Firas H. Al-Hammadan and Almas Heshmat. (2011). Determinants of Internet Use in Iraq. International Journal of Communication, 5 , 1967-1989.

Foley, S. (2013). When life imitates art: the Arab Spring, the Middle East, and the modern world. Turkish Journal of International Relations, 12, 32-46.

Gigli, S. (2004). Children, Youth and Media Around the World: An Overview of Trends \& Issues. 4th World Summit on Media for Children and Adolescents.

Hoechsmann, M. (2008). Youth Cultural Production and the New Media. Journal of Curriculum Theorizing, 24, 60-70.

Huntington, S.P \& Nelson, J.M. (1976). No essay choice: political participation in developing countries. [online] Available: http://www.oup. com/uk/orc/bin/9780199574971/01student/additional/ch18/01/ ( Dicember 31, 2012).

Johnson, G.M. (2010). Internet Use and Child Development: The Techno-Microsystem Australian Journal of Educational \& Developmental Psychology, 10, 32 - 43.

Kayode, A.L. (2011). Youth Activism, Social Media And Nation Building. [Online] Available: http://iiumgcya2011.files.wordpress.com/ 2011/05/ paper1-lateef.pdf (March 2, 2012).

Kirkman, G.S., Cornelius, P.K., Sachs, J.D., Schwab, Klaus. (2002). The Global Information Technology Report 2001-2002: Readiness for the Networked World. [Online] Available: https://cyber.law.harvard.edu/publications/2002 (May 15, 2015).

Loader, B. D. (2007). Young citizen in the digital age: disaffected or displaced. In. Loader, B. D (Ed.), Young citizen in the Digital Age: Political engagement, young people and new media (pp.1-18). New York: Routledge Taylor \& Francis Group. 
Livingstone, S., Couldry, N., Markham, T. (2007). Youthful steps towards civic participation: does Internet help. In. Loader, B. D. (Eds.), Young citizen in the Digital Age: Political engagement, young people and new media, (pp. 21-34). New York: Taylor \& Francis Group.

Marco, M. S \& Grace, K. (2011). Do facebook and video games promote political participation among youth?: Evidence from Singapore: Journal of Democracy and Open Government, 3, 70-79.

Moeller, J., de Vreese, C., Esser,F \& Kunz, R. (2014). Pathway to political participation: the influence of online and offline news media on internal efficacy and turnout of first-time voters. American Behavioral Scientist, 58, 689 -700.

McClurg, S.D. (2003). Socio network and political participation: the role of social interaction in explaining political participation. (Online) Available: opensiuc.lib.siu.edu/cgi/viewcontent (May 18, 2015).

McQuail, D. (2010). Mass Communication Theory. $6^{\text {th }}$ edition. London: Sage.

Palfrey, J. and Gasser, U. (2008). Born Digital: Understanding the First Generation of Digital Natives. New York: Basic Books.

Porta, D \& Mosca, L. (2005). Global-net for global movements? A network of networks for a movement of movements. Journal of Public Policy, 25, 165-190.

Samsudin A. Rahim. (2010). Media, demokrasi dan generasi muda : analisis keputusan pilihan raya umum ke-12. Jurnal Komunikasi; Malaysian Journal of Communication, 26, 1-15.

Theocharis, Y. (2011). Cuts, Tweets, Solidarity and Mobilisation: How the Internet Shaped the Student Occupations. Parliamentary Affairs, 65, 162-194.

Vromen, A. (2007). Australian young people's participatory practices and internet use. Journal of Information, communication and society, 10,48-68.

Wallis, C. (2011). New Media Practices in China: Youth Patterns, Processes, and Politics. International Journal of Communication, 5, 406-436.

Weigel, M., Davis, K., James, C., \& Gardner, H. (2009). New Digital Media, Social Institutions and the Changing Roles of Youth. Retrieved from http://www.goodworkproject.org/wp-content/uploads/2010/10/No-61-NDM-Social-Institutions-Changing-Roles-ofYouth.pdf (March 7, 2012).

Waller, L. G. (2013). Enhancing political participation in jamaica: the use of Facebook to "cure" the problem of political talk among the Jamaican youth. SAGE Open, 3, 1-9.

Wojcieszak, M. \& Smith, B. (2013). Will politics be tweeted? New media use by Iranian youth in 2011. New media \& society, 1-19. 